Atmos. Meas. Tech. Discuss., 2, 1663-1692, 2009

www.atmos-meas-tech-discuss.net/2/1663/2009/

(C) Author(s) 2009. This work is distributed under

the Creative Commons Attribution 3.0 License.

\title{
DOAS
}

B. Zhou et al.

\section{Determination of an effective trace gas mixing height by differential optical absorption spectroscopy (DOAS)}

\section{B. Zhou ${ }^{1}$, S. N. Yang ${ }^{1}$, S. S. Wang ${ }^{1}$, and T. Wagner ${ }^{2}$}

${ }^{1}$ Department of Environmental Science and Engineering, Fudan University, Shanghai, China ${ }^{2}$ Max Planck Institute for Chemistry, Mainz, Germany

Received: 2 July 2009 - Accepted: 7 July 2009 - Published: 20 July 2009

Correspondence to: B. Zhou (binzhou @fudan.edu.cn)

Published by Copernicus Publications on behalf of the European Geosciences Union.

\section{Title Page}

Abstract

Introduction

Conclusions

References

Tables

Figures

14

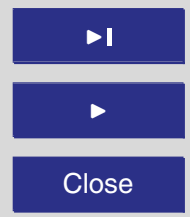

Full Screen / Esc

Printer-friendly Version

Interactive Discussion 


\section{Abstract}

A new method for the determination of the Mixing layer Height $(\mathrm{MH})$ by the DOAS technique is proposed in this article. The $\mathrm{MH}$ can be retrieved by a combination of active DOAS and passive DOAS observations of atmospheric trace gases; here we

5 focus on observations of $\mathrm{NO}_{2}$. Because our observations are sensitive to the vertical distribution of trace gases, we refer to the retrieved layer height as an "effective trace gas mixing height" (ETMH). By analyzing trace gas observations in Shanghai over one year (1017 hourly means in 93 days in 2007), the retrieved ETMH was found to range between $0.1 \mathrm{~km}$ and $2.8 \mathrm{~km}$ (average is $0.78 \mathrm{~km}$ ); more than $90 \%$ of the measurements yield an ETMH between $0.2 \mathrm{~km}$ and $2.0 \mathrm{~km}$. The seasonal and diurnal variation of the ETMH shows good agreement with mixing layer heights derived from meteorological observations. We investigated the relationship of the derived ETMH to temperature and wind speed and found correlation coefficients of 0.65 and 0.37 , respectively. Also the wind direction has an impact on the measurement to some extent. Especially in cases 15 when the air flow comes from highly polluted areas and the atmospheric lifetime of $\mathrm{NO}_{2}$ is long (e.g. in winter), the $\mathrm{NO}_{2}$ concentration at high altitudes over the measurement site can be enhanced, which leads to an overestimation of the $\mathrm{ETMH}$. Enhanced $\mathrm{NO}_{2}$ concentrations in the free atmosphere and heterogeneity within the mixing layer can cause additional uncertainties. Our method could be easily extended to other species like e.g. $\mathrm{SO}_{2}, \mathrm{HCHO}$ or Glyoxal. Simultaneous studies of these molecules could yield valuable information on their respective atmospheric lifetimes.

\section{Introduction}

Pollutants emitted into the atmospheric boundary layer are dispersed horizontally and vertically through atmospheric turbulence and convection, and finally can become completely mixed over this layer that is widely known as "mixing layer". Mixing height $(\mathrm{MH})$ has a close relation to meteorological conditions, and meanwhile is a key input pa-

DOAS

B. Zhou et al.

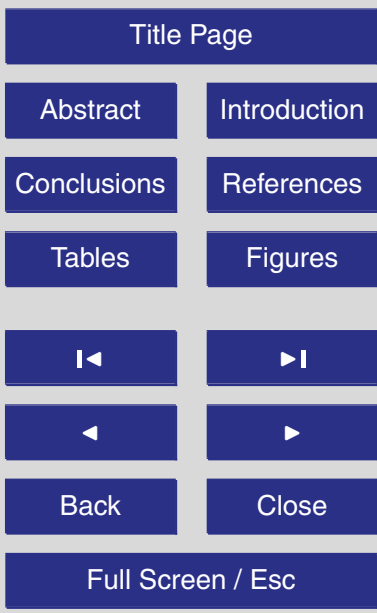

Printer-friendly Version

Interactive Discussion 
rameter to many air quality forecast models. $\mathrm{MH}$ determines the volume available for the dispersion of pollutants, so it is of particular importance in the prediction models of pollutants concentration. However, the $\mathrm{MH}$ is not a meteorological parameter that can be directly measured, and moreover the determination and assessment of it is still 5 difficult.

There are two main approaches available for the estimation of $\mathrm{MH}$. One is through analyzing profiles of meteorological parameters, such as temperature, pressure, humidity, and aerosol, and the profiles are attained with remote sensing techniques such as Radiosoundings, tethered balloon, mast, doppler weather radar/wind profiler, Li10 dar, and Sodar. $\mathrm{MH}$ could also be retrieved by analyzing temperature and pressure profiles from temperature and pressure sensors on commercial planes. Each method has its own advantages and disadvantages, because they can not give attention to all the aspects such as observing range, temporal and spatial resolution, measurement precision, instrument and operation cost (Seibert et al., 2000).

15 The second approach makes use of models based on meteorological data. The first method can provide high temporal and spatial resolution information on the $\mathrm{MH}$. Although widely used, the latter may entail uncertainties in the estimation of $\mathrm{MH}$ as discussed by certain authors (He et al., 2006; Berman et al., 1997; García, 2007).

In this study we introduce a new technique for the estimation of the $\mathrm{MH}$, which is directly related to the mixing processes of pollutants. The method is based on a combination of active and passive differential optical absorption spectroscopy (DOAS) observations of $\mathrm{NO}_{2}$ (also other trace gases could be used). Because our observations are sensitive to the vertical distribution of trace gases, we refer to the retrieved layer height as an "effective trace gas mixing height" (ETMH).

$25 \quad$ Since introduced in the 1970s (Perner and Platt, 1979; Noxon, 1975; Platt, 1994; Evangelisti et al., 1995; Solomon et al., 1999), the DOAS method has been improved rapidly and is mainly applied in atmospheric research. The DOAS technique is based on the absorption of ultraviolet (UV) and visible light along specific light paths by atmospheric molecules. Passive DOAS observations typically use the scattered sun light

\section{AMTD}

2, 1663-1692, 2009

\section{DOAS}

B. Zhou et al.

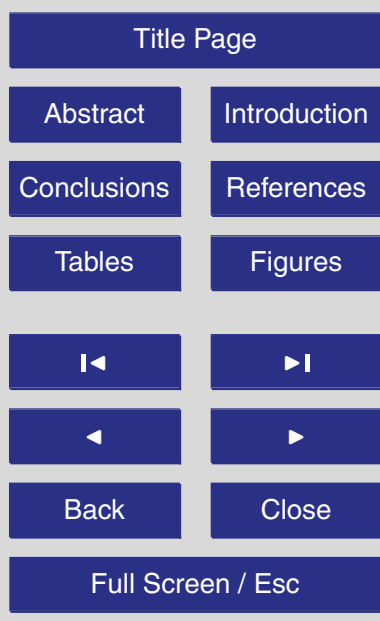

Printer-friendly Version

Interactive Discussion 
as light source, and vertically integrated trace gas concentrations are usually retrieved. Recently, (Chen et al., 2009) introduced a detailed method for the determination of the vertically integrated tropospheric $\mathrm{NO}_{2}$ concentration from passive DOAS observations of zenith scattered light. Active DOAS observations utilize artificial light sources, and average surface concentrations of trace gases are retrieved.

The DOAS technique has been developed to measure many atmospheric trace gases, such as $\mathrm{O}_{3}, \mathrm{NO}_{2}, \mathrm{HONO}, \mathrm{SO}_{2}, \mathrm{CS}_{2}, \mathrm{BrO}, \mathrm{IO}, \mathrm{OCIO}$ and more than 30 kinds of hydrocarbons (Febo et al., 1996; Vandaele et al., 2005; Hönninger et al., 2002; Kourtidis et al., 2000; Bruns et al., 2006, Platt and Stutz, 2008). $\mathrm{HONO}, \mathrm{OH}, \mathrm{NO}_{3}, \mathrm{BrO}, \mathrm{ClO}$ 10 in the troposphere and $\mathrm{OCIO}, \mathrm{BrO}$ in the stratosphere were first measured by DOAS method, the measurement precision substantial increased during recent years (Zhou et al., 2002; Qi et al., 2002).

\section{Method}

\subsection{Experimental}

15 Determination of the ETMH based on the DOAS technique by combination of active DOAS and passive DOAS could be educed by analyzing of the integrated $\mathrm{NO}_{2}$ concentrations, respectively retrieved by active DOAS and passive DOAS. The principle of active DOAS (LP-DOAS) and passive DOAS (Zenith DOAS) is shown in Fig. 1.

The light source of passive DOAS is the incoming solar irradiation. The receiving 20 telescope is directed at the zenith sky and receives scattered sun light. Since scattered light passes through the whole atmosphere, this method provides information on the total $\mathrm{NO}_{2}$ column density. After subtracting the stratospheric $\mathrm{NO}_{2}$ column density and correcting for light path effects, the vertical column density (VCD, the vertically integrated concentration) in the troposphere can be determined (Chen et al., 2009).

25 This method can be applied with good accuracy especially to observations in polluted regions. An active DOAS instrument observes light from an artificial light source over

\section{AMTD}

2, 1663-1692, 2009

\section{DOAS}

B. Zhou et al.

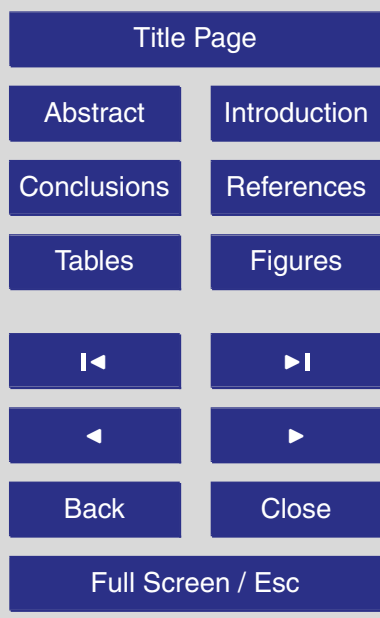

Printer-friendly Version

Interactive Discussion 
a horizontal distance. Usually the light source is at the same location as the receiver and a retro-reflector that is placed at certain distance, folds the beam back to transmitting/receiving telescope. The light transfers a double distance between transmitting/receiving telescope and retro-reflector, and thus active DOAS offers the possibility 5 to measure the integrated concentration of air pollutants in the lower atmosphere as is presented in Fig. 1 (Platt et al., 1994, 2008; Noxon, 1975; Zhou et al., 2005). The average trace gas concentration along the optical path can be derived by dividing the integrated concentration by the length of the path.

\subsection{Calculation of the effective trace gas mixing height}

10 The basic assumption of our new technique for the determination of the ETMH is that the $\mathrm{NO}_{2}$ is completely mixed in mixing layer, and its profile along with altitude can be approximated by that shown in Fig. 2.

For simplicity we then can assume that the $\mathrm{NO}_{2}$ concentration is constant within the $\mathrm{MH}$ and zero above. Then $\mathrm{N}_{\mathrm{LP} \text {-DOAS }}$ retrieved from active DOAS and $\mathrm{VCD}_{\text {ETMH }}$ retrieved from passive DOAS are directly connected via the ETMH, which can be obtained by the following formula:

$E T M H=\frac{V C D_{E T M H}}{N_{\text {Ip-DOAS }}}$.

The following example illustrates how to calculate the ETMH with this method. Figure 3 shows a comparison between results from active DOAS and passive DOAS; active DOAS data has been converted into $\mathrm{VCD}_{\mathrm{EMTH}}$ through multiplying by the ETMH. In Fig. $3 a$, the ETMH is assumed as $0.3 \mathrm{~km}$. It is found that the result of active DOAS is close to that from the passive DOAS at 8:00 and from 16:00 to 17:00. Thus we can say that our observations are in agreement with an ETMH of $0.3 \mathrm{~km}$ at these times. Figure 3b, c show similar comparisons for assumed ETMH of $0.6 \mathrm{~km}$ and $0.8 \mathrm{~km}$, re25 spectively. Good agreement with the $\mathrm{VCD}_{\mathrm{EMTH}}$ is found for other periods of the day.

\section{AMTD}

2, 1663-1692, 2009

\section{DOAS}

B. Zhou et al.

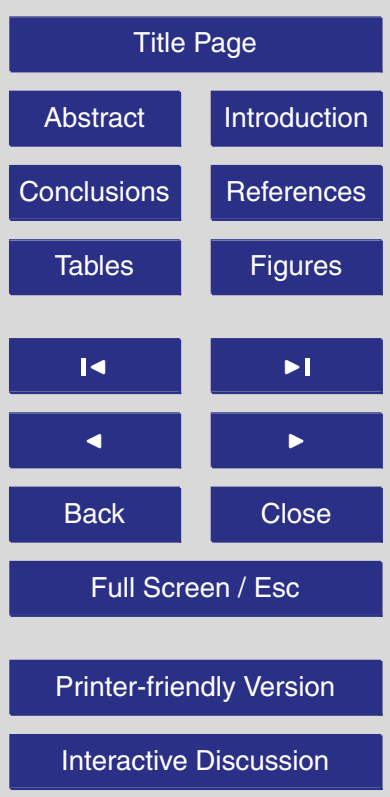


The above analysis confirms our basic assumptions, and yields results for the diurnal variation of the ETMH which are in general agreement with expectations.

It should be noted that instead of assuming a vertically constant trace gas concentration, a constant mixing ratio would be more realistic. However, for simplicity we chose

5 a constant concentration in this first study. Since the boundary layer is usually confined to the lowest $1-2 \mathrm{~km}$, the resulting errors are small, and probably usually smaller than other uncertainties. The method can in principle easily be extended using the assumption of vertically constant mixing ratio.

\section{Results}

10 To reduce a possible cloud influence on the results of passive DOAS, only observations for mainly cloud free conditions were selected. The selection was performed according to the simultaneously observed $\mathrm{O}_{4}$ absorptions (Chen et al., 2009).

Experiment is paused in July and August because of school vacation. As a result, there are valid data for 93 days during the whole year. Table 1 shows the distribution 15 of measurement days in different months. According to weather condition and season, the experiment is operated from 5:00 to 18:00 every day. In total 1017 data points of hourly averages are obtained during that period. From the hourly averaged data monthly averages (Figs. 4, 5) are calculated. Except the values in January, both the seasonal and diurnal variation of the ETMH shows the expected dependence: low 20 values occur in winter and in the morning as well as high values in summer and at noon and afternoon.

The high values in January are probably caused by the long lifetime of $\mathrm{NO}_{\mathrm{x}}$ in the troposphere during winter. Under such conditions, local measurements can be strongly influenced by emissions from distant sources. Since the method relies on the as25 sumption of rapid mixing of local emissions, measurement results retrieved under such conditions have to be treated with care (for more details see Sect. 4.3).

\section{AMTD}

2, 1663-1692, 2009

\section{DOAS}

B. Zhou et al.

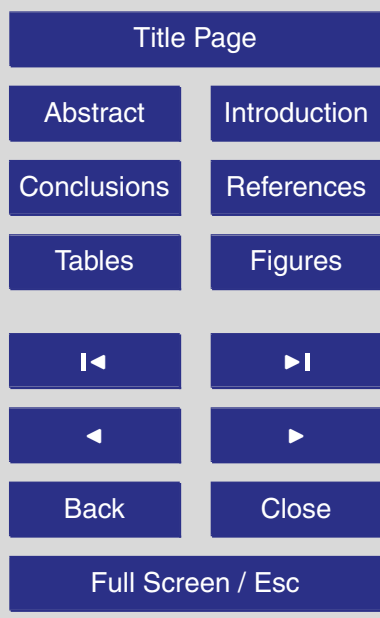

Printer-friendly Version

Interactive Discussion 
Due to limited space, it is impossible to illustrate every day's data. We will systematically discuss them in the next section.

\section{Discussion}

Mixing layer height is governed by many factors and follows a systematic seasonal 5 variation. Meteorological parameters strongly affect the $\mathrm{MH}$, especially surface temperature, wind speed, and wind direction. In this section we investigate the correlation between meteorological parameters and the ETMH.

\subsection{Correlation between the ETMH and surface temperature}

The variation of surface temperature controls the occurrence of atmospheric convection, so surface temperature changes have a strong effect on the $\mathrm{MH}$. This relationship is well demonstrated for the observations from 11 May 2007 (see Fig. 6). It is expected that surface temperature should have the strongest effect in summer, when the solar irradiation is strongest and days are longest in the northern hemisphere. This expectation is broadly confirmed by the results shown in Table 2 . The correlation coefficients between the ETMH and surface temperatures are highest in autumn and summer and smallest in winter and spring.

The monthly variation of the correlation coefficients between the ETMH and temperature is also presented in Fig. 7. It's a box figure, each box represents each month, where lower and higher boundaries are the 25 and 75 percentiles. The median value and the mean concentrations are respectively the solid lines and hollow squares. The low and high external lines represent the 90 and 10 percentiles while the maximum and minimum values are marked with stars outside the boxes. This graph gives more details of the data.

It can be seen in Fig. 7, that the range of means is between 0.4 and 0.84 , the lowest mean occurs in December, when the minimum is -0.818 , much less than other data of

DOAS

B. Zhou et al.

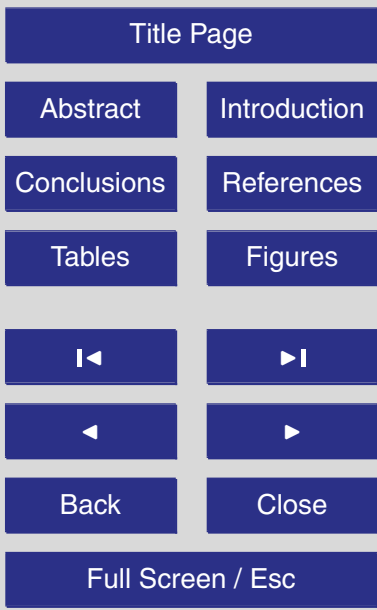

Printer-friendly Version

Interactive Discussion 
this month. But if we pay attention to the median, it can be found that the range is only from about 0.51 to 0.83 . The lowest median appears in January, while, the highest is in September (in January and December, the median is close to the lower boundaries of the boxes). It should be mentioned that, because there are too little data in March, 5 June and October, no median is calculated in those months.

In January and February, the correlation between the ETMH and temperature is a little bit lower than in other months. This might be related to the fact that in those months, the temperature is lower compared with other months, so other meteorological parameters, such as wind speed and wind direction may have a more dominant effect on the ETMH than in other months.

Although in general surface temperature has a large impact on the mixing layer, other factors play a leading role in some cases. Then the relationship between the ETMH and temperature is low. For instance, the value is -0.818 on 2 December 2007, which illuminates the ETMH variation is opposite to temperature, and other meteorological 15 factors are the dominant ones.

\subsection{Correlation between the ETMH and surface wind speed}

Wind Speed (WS) is found to be another important factor impacting the MH. Similar to the correlation analysis between the ETMH and temperature, that of ETMH and WS is calculated and analyzed. Table 3 show the results of the correlation retrieved between both quantities. The correlation coefficients are highest for winter indicating that the wind speed plays a dominant role in seasons with little solar irradiation.

The box graph of the correlation coefficients between ETMH and WS is also shown in Fig. 8. We can see in this graph, that all the means are in the range of 0.22 and 0.54 , much lower than those between ETMH and temperature. The median ranges 25 from 0.24 to 0.72 , the maximum median occurs in April. The dynamic range is larger than that between the ETMH and temperature, which indicates that in some cases, wind can dominate the ETMH, but this does not happen frequently. This also can be seen from the difference of maximum and minimum in each month.

\section{AMTD}

2, 1663-1692, 2009

\section{DOAS}

B. Zhou et al.

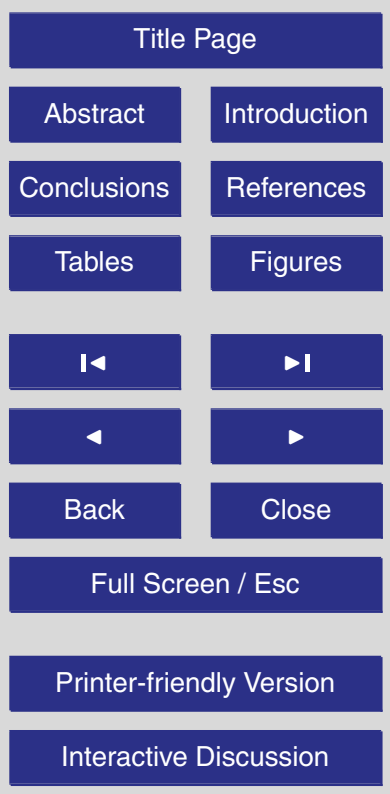

Interactive Discussion

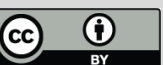


In contrast to the correlation between the ETMH and temperature, the correlation between the ETMH and wind speed in the cold season is in general larger than in the warm season. This indicates that in winter WS has a stronger effect on the ETMH than in summer.

5 On the basis of the correlation analyses, different days can be classified with respect to four situations: a) both temperature and WS show good correlation with the ETMH, as for instance on 8 May, 29 November, 13 May; b) correlation of the ETMH with temperature is high, but with WS is rather low, as for instance on 14 May, 9 November, 22 November. The occurrence of cases a) and b) are quite frequent; c) correlation 10 of the ETMH with WS is high, but with temperature is rather low, as for instance on 2 December. This case hardly appeared; d) Not only temperature but also WS is irrelevant to the ETMH, as for example on 7 and 8 December. Also the probability for case d) is very small. For these cases, other factors than temperature and WS, for example wind Direction (WD), relative humidity $(\mathrm{RH})$ and pressure $(p)$, might play 15 a dominant role.

\subsection{Influence of atmospheric lifetime on the determination of the ETMH}

The proposed method to determine the ETMH depends on two major assumptions. First, on the occurrence of an effective mixing of pollutants throughout the whole mixing layer. Second, on the fact that the local conditions are not significantly affected by 20 pollutants from distant sources. The second point can become important especially during winter time, because usually a) higher wind speeds appear and b) the $\mathrm{NO}_{\mathrm{x}}$ lifetime becomes substantially longer. Under such conditions distant sources can have a strong influence on our new method. To investigate these effects in more detail, we selected the period from 6 to 10 January. Figure 9 describes the variation of the ETMH, temperature, WS, $\mathrm{RH}$ and pressure from 6 to 10 January.

During the first part of the selected period unrealistically high ETMH were observed. For these observations, temperature was low and wind speed rather high. We also calculated back trajectories [http://www.ready.noaa.gov/hysplitarc-bin/traj1file.pl?

\section{AMTD}

2, 1663-1692, 2009

\section{DOAS}

B. Zhou et al.

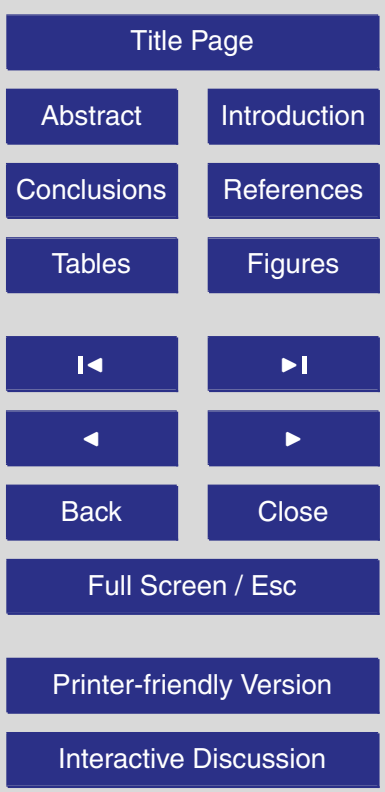

Interactive Discussion

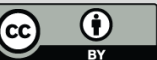


metdata=GDAS1] (see Fig. 10) and found that for 6 to 8 January the air masses came indeed from polluted sources.

In contrast, on 9 and 10 January, the air masses traversed the ocean before they arrived over the measurement site (see Fig. 10). Thus they carried less pollution com5 pared to the period from 6 to 8 January. Together with the data on WS and WD we thus can explain the reason why the ETMH of the first days is larger than on the following days. The observations in January 2008 indicate a general limitation of our method, which is most pronounced in winter. Under such conditions, the passive DOAS might observe $\mathrm{NO}_{2}$ at higher altitude, which is transported from distant sources but which 10 can not be observed by the active DOAS. This effect will lead to an overestimation of the ETMH according to Eq. (1).

\subsection{Comparison with other results}

Yang et al. studied resent 15 years $\mathrm{MH}$ variation at 2:00, 8:00, 14:00 and 20:00 from 1990 to 2004 in Shanghai (Yang et al., 2006). In their study, daily MH were calculated based on atmospheric stability and wind speed on the surface (10 $\mathrm{m}$ above ground) according to the national standard (GB/T 13201 91) of China. Unfortunately, there is no temporal overlap between their results and our observations. However, since Yang's results are 15 years averages, they might well be representative for the seasonal variation of the ETMH in Shanghai. In Table 4, we compare the ETMH at t 8:00 and 20 14:00 with their results (see also Fig. 4).

The ETMH derived from the DOAS observations is nearly $22 \%$ lower than the mean $\mathrm{MH}$ at 8:00, but it is about 14\% larger at 14:00. However, it should be noted that in Yang's results also substantial differences are found for different years: the minimum of the $\mathrm{MH}$ appeared in $1995(0.57 \mathrm{~km}$ at $8: 00$ and $0.82 \mathrm{~km}$ at $14: 00)$, while the maximum appeared in 2004 (0.68 $\mathrm{km}$ and $0.91 \mathrm{~km}$ at 8:00 and 14:00, respectively).

Taking into account that the ETMH and $\mathrm{MH}$ are derived by two completely different methods, the differences between both data sets are rather small.

Figure 11 shows the annually averaged daily variation of the ETMH from 7:00 to 
16:00 in 2007 (A). The maximum of the ETMH occurs is at 14:00. This is similar to the results from Yang et al. (B).

\section{Errors of the method}

Errors of the ETMH derived from the combination of active DOAS and passive DOAS 5 origin from uncertainties of the assumed $\mathrm{NO}_{2}$ vertical distribution profile and measurement errors of the two instrument themselves.

As shown in Fig. 1, our method is based on the assumption of a specified vertical profile; in our case a constant $\mathrm{NO}_{2}$ concentration was assumed. Of course, the real profile will in general differ from this assumed profile. An additional, but associated error results from the fact that the passive DOAS detects $\mathrm{NO}_{2}$ not only in the mixing layer but also in the free troposphere. If considerable $\mathrm{NO}_{2}$ exists in free troposphere, it will be erroneously regarded as being in the mixing layer. Consequently, this effect leads to an overestimation of the retrieved ETMH. Suppose that the $\mathrm{NO}_{2}$ concentration in the free troposphere is 2 of that in the mixing layer and that the free troposphere 15 is five times as high as the mixing layer. The resulting error of the retrieved ETMH according to Eq. (3) would be $10 \%$. As mentioned above, if temperature in winter is low and wind comes from inland high-polluted areas, it will bring $\mathrm{NO}_{2}$ to Shanghai, part of it might be present at high altitudes in the free troposphere. This can lead to a strong overestimation of the true ETMH (see Sect. 4.3).

20 If the concentration of $\mathrm{NO}_{2}$ is small, measurement errors of the instruments themselves can become the dominating error source. The uncertainty of the passive DOAS instrument is about $>50 \%$ for $\mathrm{NO}_{2} \mathrm{VCDs}<0.5 \times 10^{16} \mathrm{molec} / \mathrm{cm}^{2}$. That means that for $\mathrm{VCD}_{\mathrm{ETMH}}$ in that range or below, the uncertainties of the method becomes larger than $50 \%$. Note, however, that in Shanghai, typical $\mathrm{VCD}_{\mathrm{ETMH}}$ are by far larger and the respective errors are smaller (Chen et al., 2009).

Similarly, also for low surface concentrations derived from the active DOAS, the uncertainties of the ETMH increase, since this quantity appears in the denominator of

DOAS

B. Zhou et al.

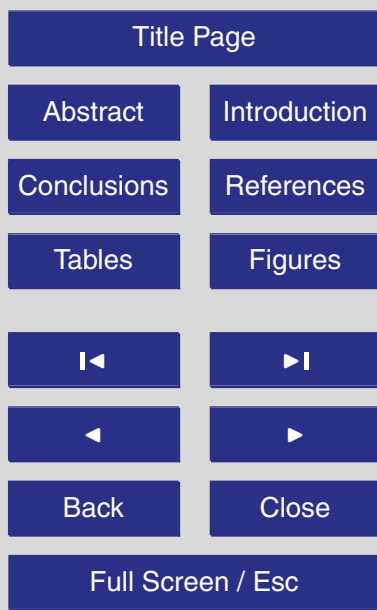

Printer-friendly Version

Interactive Discussion 
Eq. (1). This might become especially important if a systematic bias exists for the data from the active DOAS. For low values of the analysed surface concentrations, even small systematic biases can lead to strong systematic deviations of the derived ETMH. This might be one potential reason for the rather high values of the ETMH in May (see

5 Fig. 5). In those months many observations of the active DOAS yielded rather small surface concentrations of $\mathrm{NO}_{2}$.

In addition to vertical gradients of the $\mathrm{NO}_{2}$ concentration within the mixing layer, also horizontal gradients affect the retrieval. If, for example, an air mass with higher $\mathrm{NO}_{2}$ concentration emerges at low altitude over the measurement site, it will increase the 10 results of the active DOAS leading to an underestimation of the $\mathrm{MH}$. However, since in this study hourly averages are used, this effect should be rather small.

\section{Conclusions}

We introduced a new method for the determination of the mixing layer height by combination of active DOAS and passive DOAS observations of $\mathrm{NO}_{2}$. In contrast to con15 ventional definitions of the mixing layer height, our method is sensitive to the vertical distribution of trace gases; thus we refer to the retrieved layer height as an "effective trace gas mixing height" (ETMH). Depending on the atmospheric lifetime and vertical exchange, the ETMH could differ systematically from the meteorological mixing layer height. However, for several applications, the ETMH might be a well suited quantity, especially for studies with focus on the dispersion and transport of pollutants.

We analysed trace gas observations in Shanghai over one year (1017 hourly means in 93 days in 2007), and found the ETMH to range between $0.1 \mathrm{~km}$ and $2.8 \mathrm{~km}$ (average is $0.78 \mathrm{~km}$ ); more than $90 \%$ of the measurements yield an ETMH between $0.2 \mathrm{~km}$ and $2.0 \mathrm{~km}$. The seasonal and diurnal variation of the ETMH shows good agreement with mixing layer heights derived from meteorological observations (Yang et al., 2006).

Finally, we investigated the relationship of the derived ETMH to temperature and wind speed and found correlation coefficients of 0.65 and 0.37 , respectively. Also the

\section{AMTD}

2, 1663-1692, 2009

\section{DOAS}

B. Zhou et al.

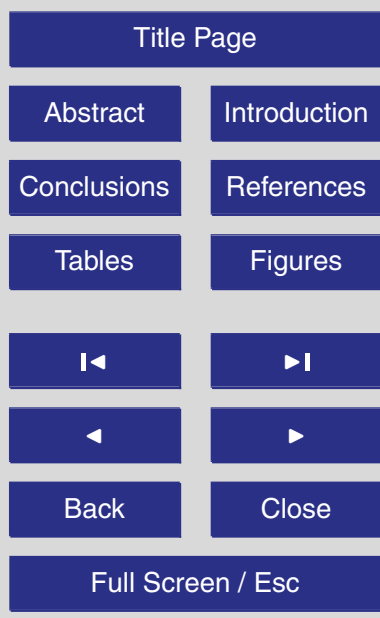

Printer-friendly Version

Interactive Discussion 
wind direction has an impact on the measurement to some extent. Especially in cases when the air flow comes from highly polluted areas and the atmospheric lifetime of $\mathrm{NO}_{2}$ is long (e.g. in winter), the $\mathrm{NO}_{2}$ concentration at high altitudes over the measurement site can be enhanced, which leads to an overestimation of the $\mathrm{ETMH}$. Enhanced $\mathrm{NO}_{2}$ 5 concentrations in the free atmosphere and heterogeneity within the mixing layer can cause additional uncertainties.

Our method could be easily extended to other species like e.g. $\mathrm{SO}_{2}, \mathrm{HCHO}$ or Glyoxal. Simultaneous studies of these molecules could yield valuable information on their respective atmospheric lifetimes.

10 Acknowledgements. We thank the National High-tech R\&D Program of China for supporting this research. We also acknowledge Chen Dan's former research work for this study. Fund Program: supported by "863 project", No: 2006AA06Z417

\section{References}

Berman, S., Yeong, J. K., Zhang, J., and Rao, T.: Uncertainties in estimating the mixing depth - comparing three mixing-depth models with profiler measurements, Atmos. Environ., 31, 3023-3039, 1997.

Bruns, M., Buehler, S. A., Burrows, J. P., Richter, A., Rozanov, A., Wang, P., Heue, K. P., Platt, U., Pundt, I., and Wagner, T.: $\mathrm{NO}_{2}$ Profile retrieval using airborne multi axis UV-visible skylight absorption measurements over central Europe, Atmos. Chem. Phys., 6, 3049-3058, 2006, http://www.atmos-chem-phys.net/6/3049/2006/.

Chen, D., Zhou, B., Beirle, S., Chen, L. M., and Wagner, T.: Tropospheric $\mathrm{NO}_{2}$ column densities deduced from zenith-sky DOAS measurements in Shanghai, China, and their application to satellite validation, Atmos. Chem. Phys., 9, 3641-3662, 2009,

25 http://www.atmos-chem-phys.net/9/3641/2009/.

Evangelisti, F., Baroncelli, A., Bonasoni, P., Giovanelli, G., and Ravegnani, F.: Differential optical absorption spectrometer for measurement of tropospheric pollutants, Appl. Optics, 34, 27372744, 1995.

\section{DOAS}

B. Zhou et al.

\section{Title Page}

Abstract Introduction

Conclusions
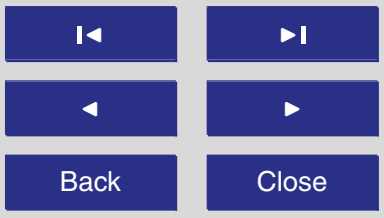

Back

Full Screen / Esc

Printer-friendly Version

Interactive Discussion 
Febo, A., Perrino, C., and Allegrini, I.: Measurement of nitrous acid in Milan, Italy, by DOAS and diffusion ednuders [J], Atmos. Environ., 30, 3599-3609, 1996.

García, M. A., S'anchez, M. L., de Torre, B., and Pérez, I. A.: Characterisation of the mixing height temporal evolution by means of a laser dial system in an urban area - intercomparison

5 results with a model application, Ann. Geophys., 25, 2119-2124, 2007, http://www.ann-geophys.net/25/2119/2007/.

He, Q. S., Mao, J. T., Chen, J. Y., and Hu, Y. Y.: Observational and modelling studies of urban atmospheric boundary-layer height and its evolution mechanisms, Atmos. Environ., 40, 1064-1077, 2006.

10 Hönninger, $\mathrm{G}$. and Platt, U.: The role of $\mathrm{BrO}$ and its vertical distribution during surface ozone depletion at Alert, Atmos. Environ., 36, 2481-2489, 2002.

Kourtidis, K., Ziomas, I., Zerefos, C., Gousopoulos, A., Balis, D., and Tzoumaka, P.: Benzene and toluene levels measured with a commercial DOAS system in Thessaloniki, Atmos. Environ., 34, 1471-1480, 2000.

15 Noxon, J. F.: Nitrogen dioxide in the stratosphere and troposphere measured by ground-based absorption spectroscopy, Science, 189, 547-549, 1975.

Perner, D. and Platt, U.: Detection of nitrous acid in the atmosphere by differential optical absorption, Geophys. Res. Lett., 6, 917-920, 1979.

Platt, U.: Differential optical absorption spectroscopy (DOAS), in: Air monitoring by spectroscopic techniques, edited by: Sigrist, M. W., Chem. Anal. Ser., 127, 27-84, 1994.

Platt, U. and Stutz, J.: Differential Optical Absorption Spectroscopy - Principles and Applications, Springer-Verlag Berlin Heidelberg, 2008.

Qi, F., Liu, W. Q., Zhou, B., Li, Z. B., and Chui, Y. J.: Improving DOAS System Measurement Precision with Artificial Neutral Network Method, Acta Optica Sinica, 22, 1346-1349, 2002.

Seibert, P., Beyrich, F., Gryning, S.-E., Joffre, S., Rasmussen, A., and Tercier, P.: Review and intercomparison of operational methods for the determination of the mixing height, Atmos. Environ., 34, 1001-1027, 2000.

Solomon, S., Portmann, R. W., Sanders, R. W., Daniel, J. S., Madsen, W., Bartram, B., and Dutton, E. G.: On the role of nitrogen dioxide in the absorption of solar radiation, J. Geophys. 30 Res., 104, 12047-12058, 1999.

Vandaele, A. C., Fayt, C., Hendrick, F., Hermans, C., Humbled, F., van Roozendael, M., Gil, M., Navarro, M., Puentedura, O., Yela, M., Braathen, G., Stebel, K., Tørnkvist, K., Johnston, P., Kreher, K., Goutail, F., Mieville, A., Pommereau, J.-P., Khaikine, S., Richter, A., Oetjen, H.,

\section{DOAS}

B. Zhou et al.

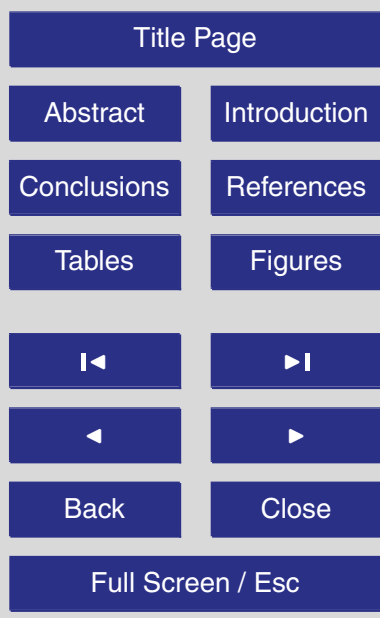

Printer-friendly Version

Interactive Discussion 
Wittrock, F., Bugarski, S., Frie, U., Pfeilsticker, K., Sinreich, R., Wagner, T., Corlett, G., and Leigh, R.: An intercomparison campaign of ground-based UV-visible measurements of $\mathrm{NO}_{2}$, $\mathrm{BrO}$, and $\mathrm{OClO}$ slant columns: Methods of analysis and results for $\mathrm{NO}_{2}$, J. Geophys. Res., 110, D08305, doi:10.1029/2004JD005423, 2005.

5 Yang, Y. J.,Tan, J. G., Zheng, Y. F., and Cheng, S.H.: Study on the atmospheric stabilities and the thickness of atmospheric mixed layer during recent 15 years in Shanghai, Scientia Meteorolo Gica Sinica, 26, 537-541, 2006.

Zhou B., Hao, N., and Chen, L. M.: A study on the effect of Fraunhofer structure on the measurement of atmospheric pollutants with differential optical absorption spectroscopy, Acta Phys. Sin-Ch. Ed., 9, 4445-4450, 2005.

Zhou, B., Liu, W. Q., Qi, F. Li, Z. B., and Chui, Y. J., Error analysis in Differential Optical Absorption Spectroscopy, Acta Optica Sinica, 22, 957-961, 2002.

AMTD

2, 1663-1692, 2009

\section{DOAS}

B. Zhou et al.

\section{Title Page}

Abstract

Introduction

Conclusions

References

Tables

Figures

14

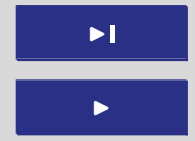

4

Back

Close

Full Screen / Esc

Printer-friendly Version

Interactive Discussion 


\section{DOAS}

B. Zhou et al.

Table 1. Number of measurement days in each month.

\begin{tabular}{ccccccccccc}
\hline & Jan & Feb & Mar & Apr & May & Jun & Sep & Oct & Nov & Dec \\
\hline Days & 7 & 12 & 4 & 15 & 12 & 3 & 7 & 8 & 15 & 10
\end{tabular}

Title Page

Abstract

Introduction

Conclusions

References

Tables

Figures

14

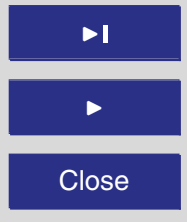

Full Screen / Esc

Printer-friendly Version

Interactive Discussion

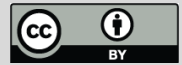




\section{DOAS}

B. Zhou et al.

Table 2. Correlation between the ETMH and surface temperature for different seasons.

\begin{tabular}{lc}
\hline Season & Correlation coefficient \\
\hline Spring & 0.59 \\
Summer & 0.7 \\
Autumn & 0.81 \\
Winter & 0.68 \\
\hline
\end{tabular}

Title Page

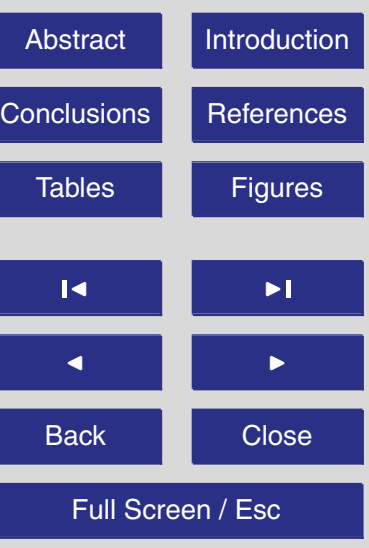

Printer-friendly Version

Interactive Discussion

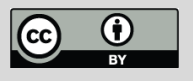


AMTD

2, 1663-1692, 2009

\section{DOAS}

B. Zhou et al.

Table 3. Correlation between ETMH and wind speed for different seasons.

\begin{tabular}{lc}
\hline Season & Correlation coefficient \\
\hline Spring & 0.43 \\
Summer & 0.38 \\
Autumn & 0.22 \\
Winter & 0.48 \\
\hline
\end{tabular}

Title Page

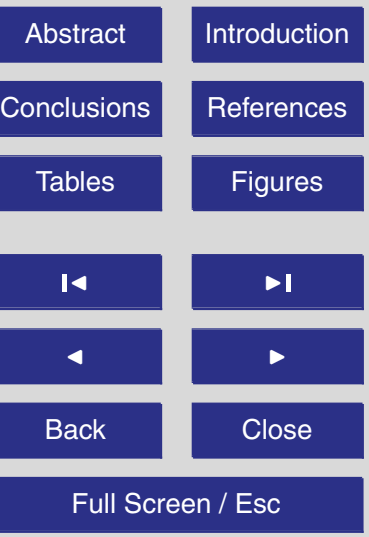

Printer-friendly Version

Interactive Discussion 


\section{DOAS}

B. Zhou et al.

Table 4. Comparison of the ETMH with the MH observed by Yang et al.

\begin{tabular}{lcccccc}
\hline & \multicolumn{5}{c}{ Layer height $(\mathrm{km})$} \\
Time & min & $\begin{array}{c}\text { 8:00 } \\
\text { mean }\end{array}$ & $\max$ & $\min$ & mean & $\max$ \\
\hline MH (Yang Yongjie et al.) & 0.57 & 0.63 & 0.68 & 0.82 & 0.86 & 0.91 \\
ETMH (DOAS) & $0.49(\mathrm{Sd}: 0.19)$ & $1.0(\mathrm{Sd}: 0.22)$ \\
\hline
\end{tabular}

Title Page

Abstract

Introduction

Conclusions

References

Tables

Figures

14

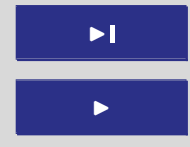

Back

Close

Full Screen / Esc

Printer-friendly Version

Interactive Discussion

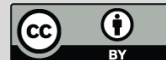




\section{DOAS}

B. Zhou et al.

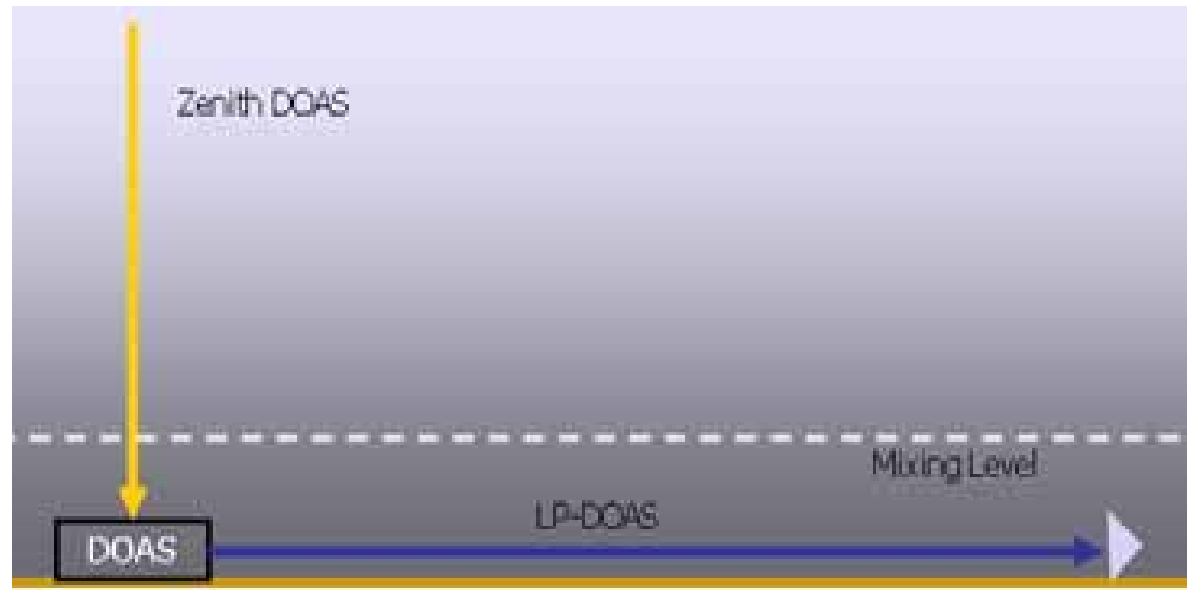

Title Page

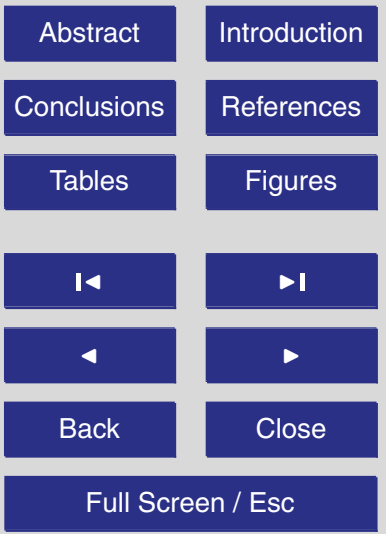

Fig. 1. Scheme of passive DOAS and active DOAS. From passive zenith sky observations, the tropospheric vertical column density is determined. From active long path observations, the average surface-near concentration is derived.

Printer-friendly Version

Interactive Discussion

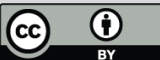




\section{DOAS}

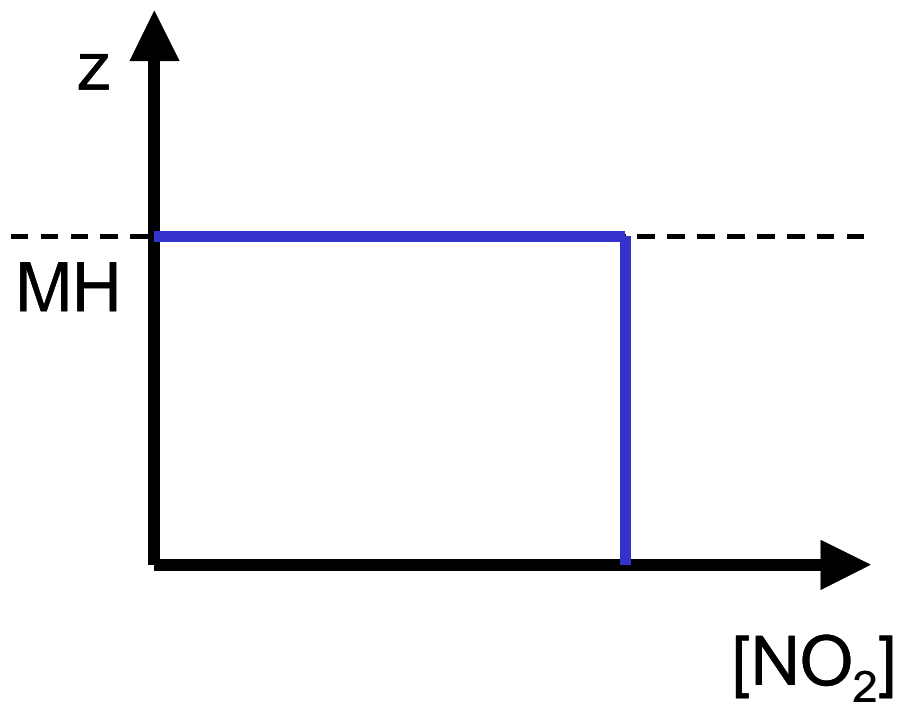

B. Zhou et al.

Title Page

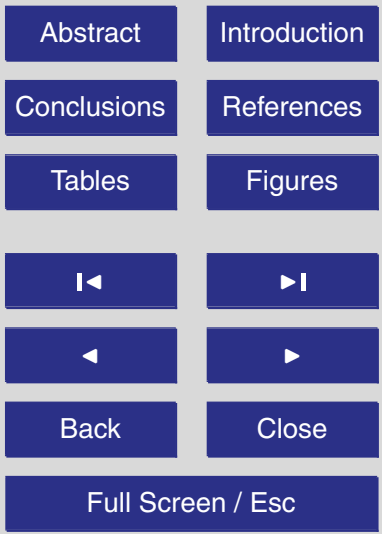

Fig. 2. Schematic tropospheric profile of $\mathrm{NO}_{2}$ with constant concentration within the $\mathrm{MH}$ and zero above.

Printer-friendly Version

Interactive Discussion

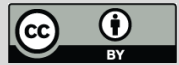


AMTD

2, 1663-1692, 2009

\section{DOAS}

B. Zhou et al.

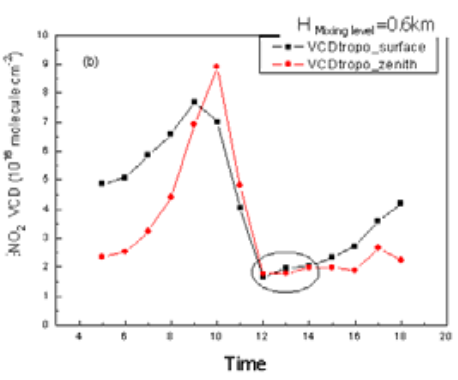

b

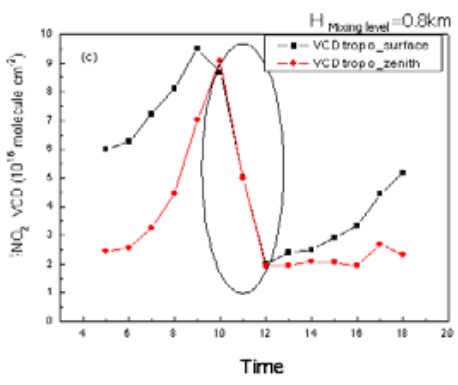

C
Fig. 3. Comparison of $\mathrm{VCD}_{\mathrm{ETML}}$ results of active DOAS and passive DOAS for different ETMH assumptions.
Title Page

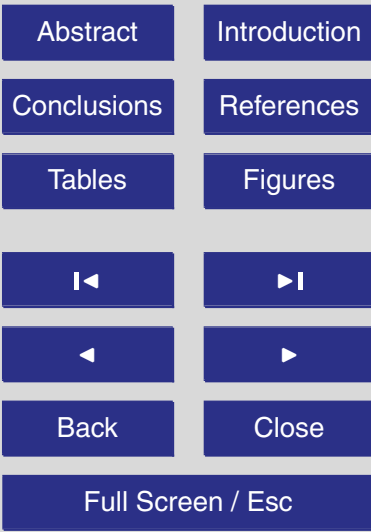

Printer-friendly Version

Interactive Discussion 


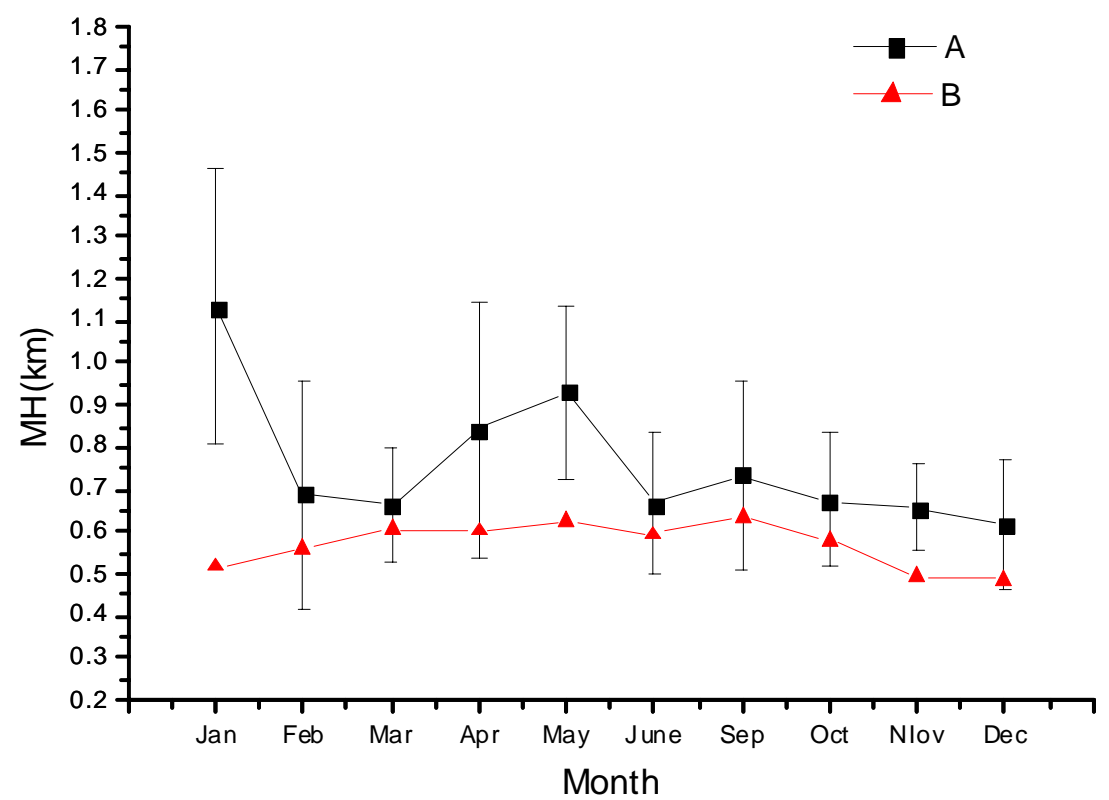

Fig. 4. (A) Monthly average ETMH in 2007. The error bars indicate the standard variation. Note that the high values in January overestimate the true values because of the long lifetime of tropospheric $\mathrm{NO}_{x}$ in winter (see Sect. 4.3). (B) Monthly average $\mathrm{MH}$ derived from meteorological data (Yang et al., 2006). Note that Yang's data include MH data at 2:00 and 20:00. Thus values systematically lower than ours should be expected.

\section{DOAS}

B. Zhou et al.

\section{Title Page}

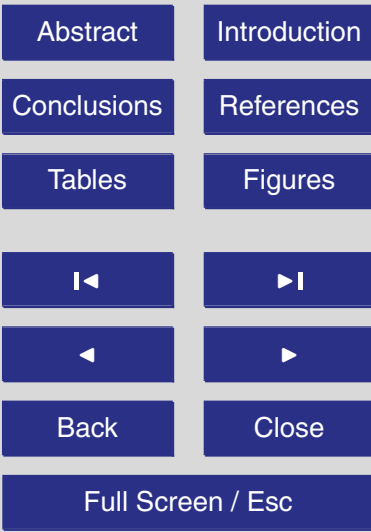

Printer-friendly Version

Interactive Discussion 
AMTD

2, 1663-1692, 2009

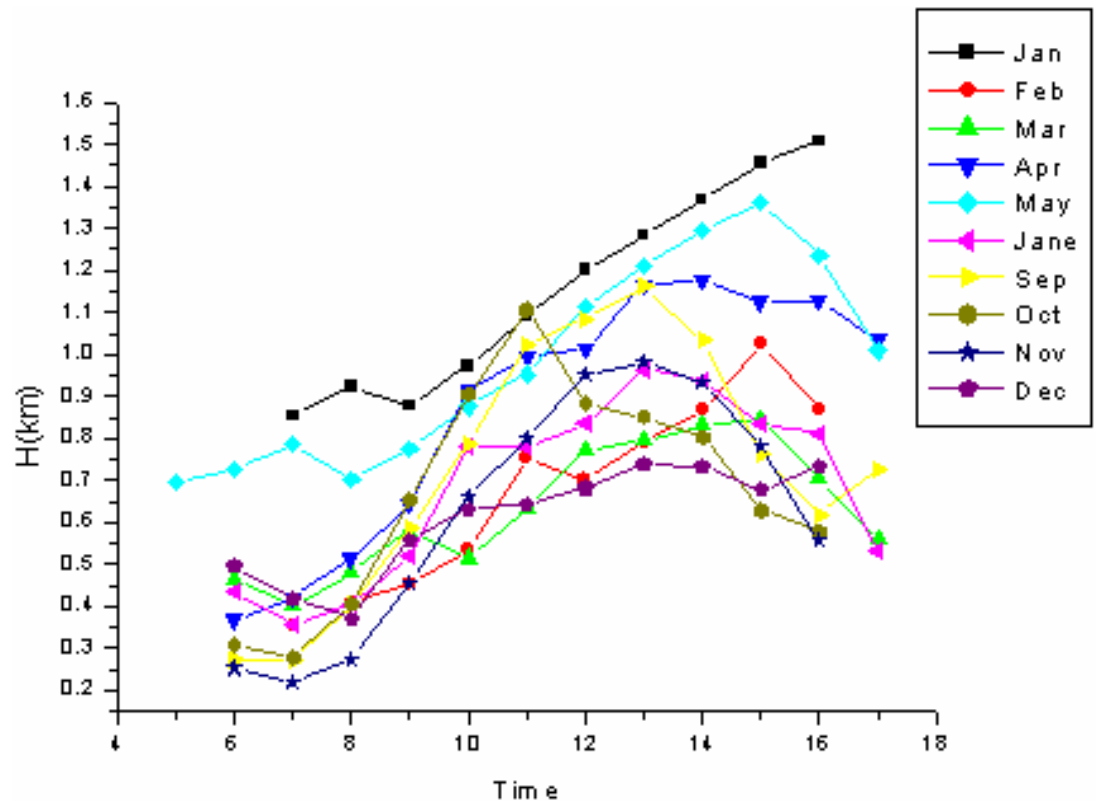

Fig. 5. Monthly averaged diurnal variation of the ETMH. Again it should be noted that the high values in January overestimate the true ETMH (see Sect. 4.3).

\section{DOAS}

B. Zhou et al.

\section{Title Page}

Abstract

Introduction

Conclusions

References

Tables

Figures

14

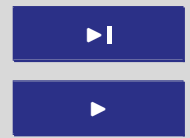

Back

Close

Full Screen / Esc

Printer-friendly Version

Interactive Discussion 
AMTD

2, 1663-1692, 2009

\section{DOAS}

B. Zhou et al.

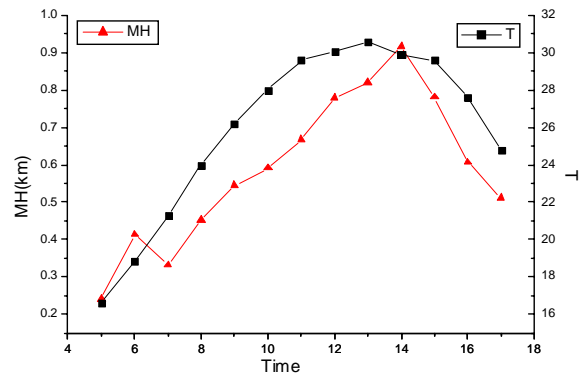

$\mathrm{a}$

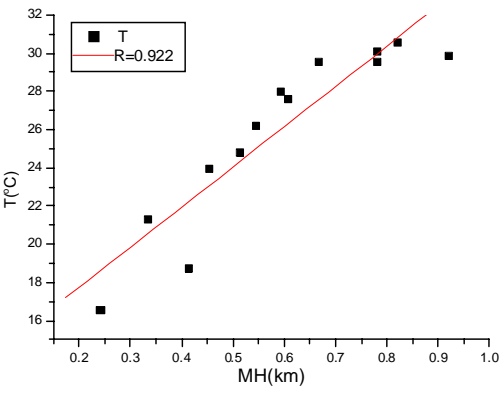

b

Fig. 6. Correlation between the ETMH and surface temperature.

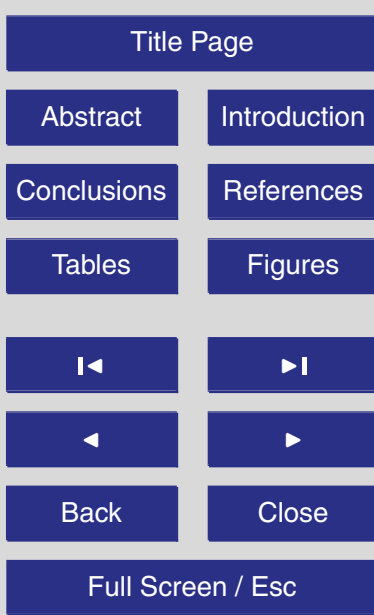

Printer-friendly Version

Interactive Discussion

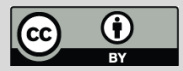


AMTD

2, 1663-1692, 2009

\section{DOAS}

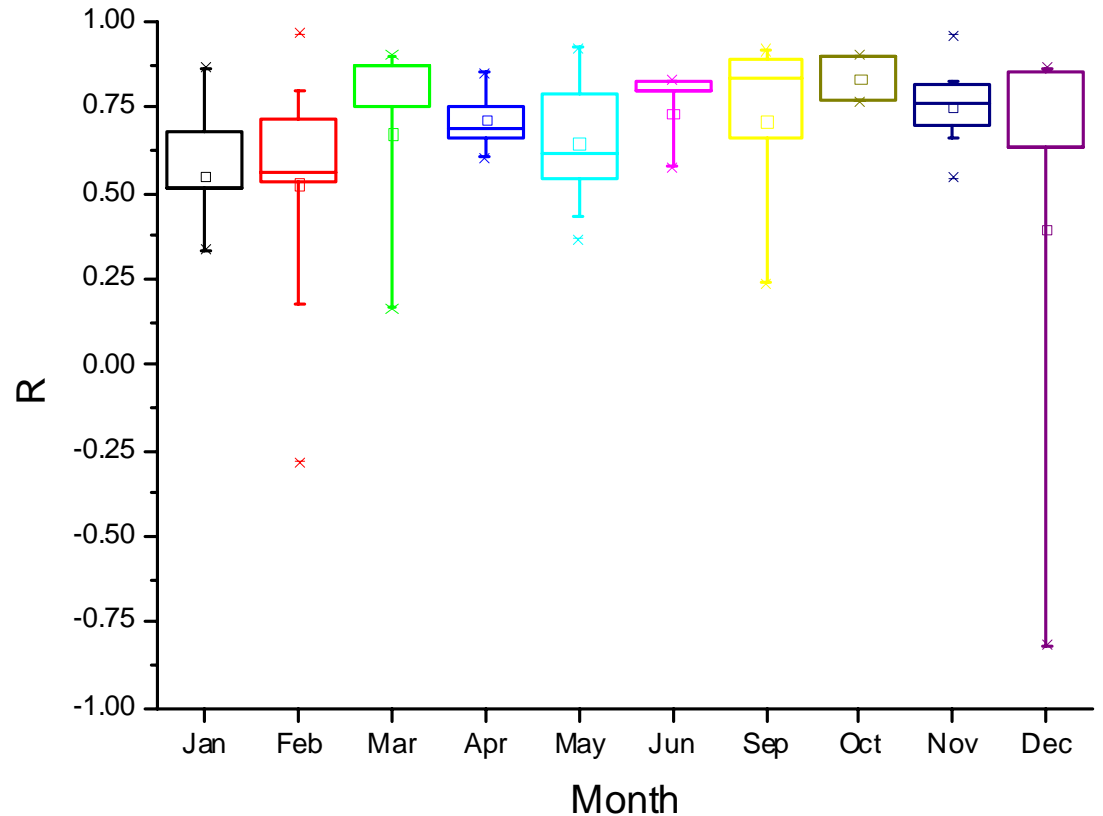

B. Zhou et al.

\section{Title Page}

Abstract

Introduction

Conclusions

References

Tables

Figures

14

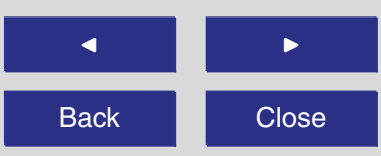

Full Screen / Esc

Printer-friendly Version

Interactive Discussion

Fig. 7. Monthly variations of the correlation between the ETMH and surface temperature.

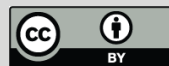


AMTD

2, 1663-1692, 2009

\section{DOAS}

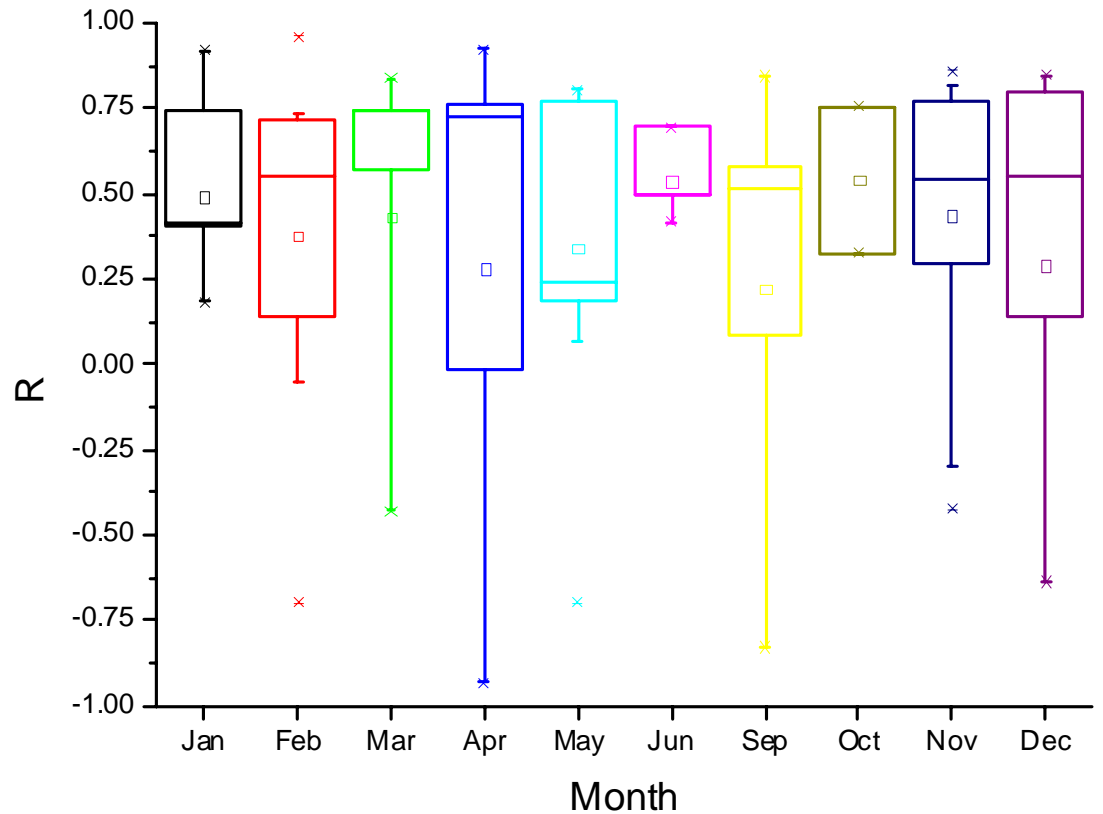

B. Zhou et al.

Title Page

Abstract

Introduction

Conclusions

References

Tables

Figures

14

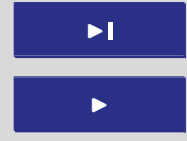

Back

Close

Full Screen / Esc

Printer-friendly Version

Interactive Discussion

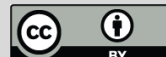



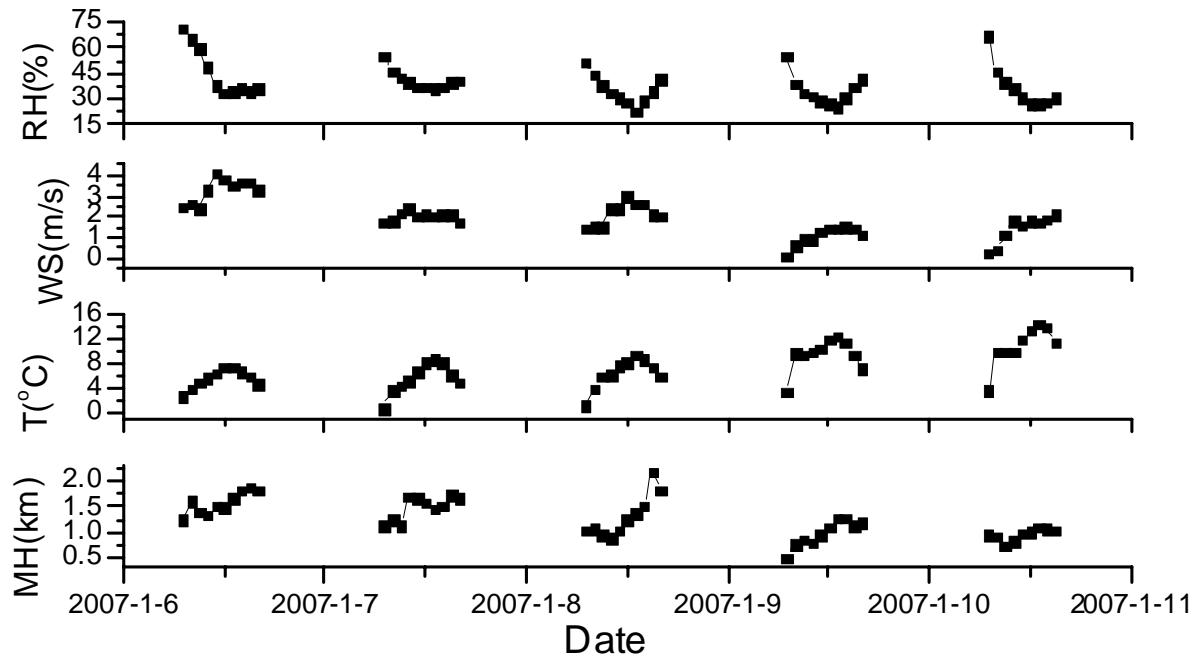

Fig. 9. Variation of the ETMH, temperature, WS, $\mathrm{RH}$ and pressure from sixth to tenth of January. The ETMH on 6, 7, 8 January is obviously higher than on 9 and 10 January, and even the lowest values exceed $0.88 \mathrm{~km}$. This phenomenon conflicts with the expectation that both the $\mathrm{MH}$ and its variation is low in winter.

\section{DOAS}

B. Zhou et al.

\section{Title Page}

Abstract

Introduction

Conclusions

References

Tables

Figures

14

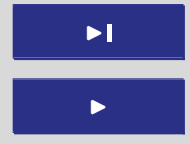

Back

Close

Full Screen / Esc

Printer-friendly Version

Interactive Discussion 


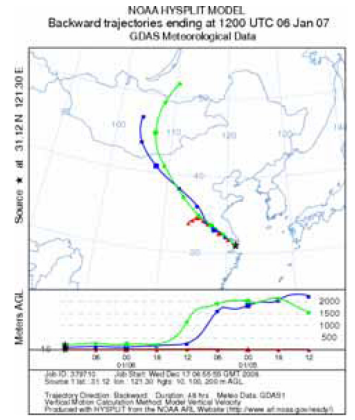

a

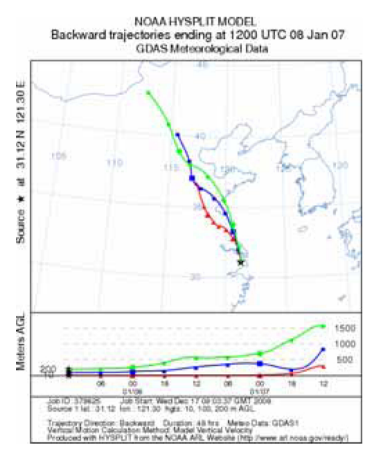

c

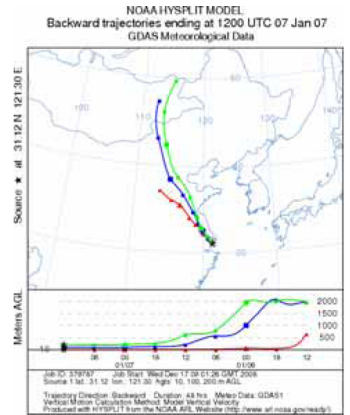

b

NOAA HYSPLIT MODLL
Backward trajectories ending at 1200 UTC 10 Jan 07

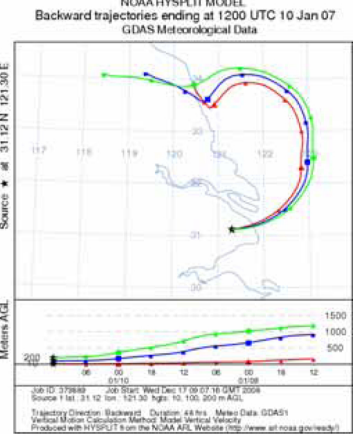

e

Fig. 10. Back trajectories (48h) arriving in Shanghai from sixth to tenth (a-e), January.

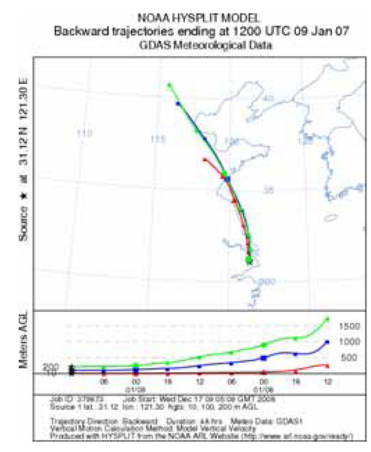

d
AMTD

2, 1663-1692, 2009

\section{DOAS}

B. Zhou et al.

Title Page

Abstract

Introduction

Conclusions

References

Tables

Figures

14

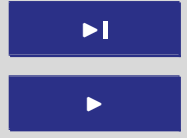

Back

Close

Full Screen / Esc

Printer-friendly Version

Interactive Discussion

(c) (1) 
AMTD

2, 1663-1692, 2009

\section{DOAS}

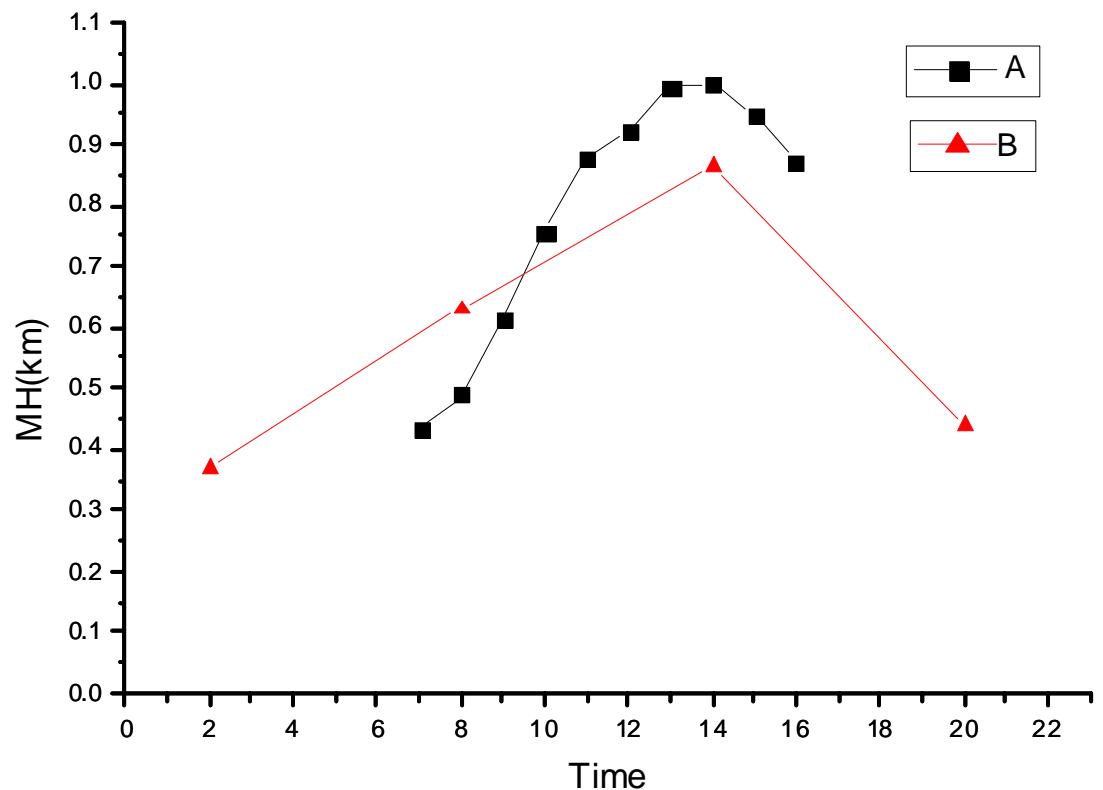

B. Zhou et al.

Title Page

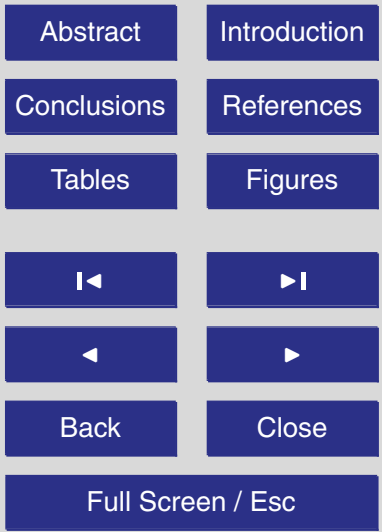

Printer-friendly Version
Fig. 11. Annually averaged daily variation of the ETMH in 2007 (A) and 15 years $\mathrm{MH}$ variation at 2:00, 8:00, 14:00 and 20:00 from 1990 to 2004 in Shanghai (B).

\section{Interactive Discussion}

